\title{
Study on Practical Teaching of Costume Art Design Major
}

\author{
Fei Wang \\ Xi'an Peihua University, Xi’an, Shaanxi, 710125
}

Keywords: costume art design; practical teaching

\begin{abstract}
With the development of society and economy, people's living standards have increased, people's demands for quality of life have become higher and higher, and so have clothing. The clothing can determine the first impression. Therefore, people pay a lot of attention to the taste of clothing, and the requirements for clothing are also varied. It is precisely for these reasons that the work of the costume art design industry has become more difficult, and more aspects need to be considered to meet the needs of different groups and different styles. The number of colleges and universities specializing in the teaching of costume art design is constantly increasing. In the teaching process, various teaching methods are applied. But students are required to practice teaching and implement the learned knowledge in practical operations. This paper mainly focuses on the relevant aspects of the practical teaching of costume art design.
\end{abstract}

\section{Introduction}

The study content of the costume art design professional is difficult. In addition to the basic theory knowledge learning, we must consider other factors, such as changes in market conditions, consumer preferences, and the country's professional policy for fashion design. Changes, laws and regulations, etc., These factors may cause the teaching plan to change at any time, and students' learning is even more difficult. In the process of teaching the students' art design majors, teachers must pay attention to the students' situations, find suitable teaching methods, and practice teaching so that students can fully apply the learned knowledge and provide fresh blood for the apparel design market.

\section{Positioning of the Costume Art Design Major}

Clothing art design, as the name suggests, is to carry out the study of clothing culture and carry out related art designs. This profession is closely related to people's lives. Everyone is inseparable from clothes. Where does the clothes come from? It was designed by the designer, tested by the market and then carried out large-scale production. It was put into the market and was finally purchased by consumers and became clothes worn by people. The costume art and design industry is a comprehensive profession. It not only needs to learn relevant clothing knowledge, but also takes into account changes in the overall needs of the society, as well as the relevant cultural and artistic knowledge, which is a test of students' comprehensive ability.

The number of students in the costume arts design major may not match the number of people in other industries, but it is definitely the essence. In the daily course of the costume art design profession, in addition to theoretical knowledge learning, more important practical learning is required. In the process of practical learning, there is a teacher who follows the course and corrects the student's problems at any time. In addition to the content of the costume design, the content of the costume art design will also include some accessories and related content of the costume show. The content of the study is rather complicated. It requires the students to develop a certain level of patience. The patience of the students is also cultivated from the daily practice.

For the costume art design profession, the country is more to give support, this new type of cultural profession not only has a great influence on people's daily life, but also plays a role in the cultural strength of a country. Since entering the 21st century, the state has implemented a series of preferential policies to support the development of the costume art design profession. In the 
professional teaching, we must learn to make full use of various advantages and cultivate higher-quality talents.

\section{Problems in the Practical Teaching of Costume Art Design}

In the day-to-day teaching of the costume art design professional, the teaching arrangement work is difficult, and once the arrangement is unreasonable, the overall teaching quality will be affected. Moreover, the teaching history of the costume art and design major is relatively short compared to other majors. There are not many precedents for reference in the difficulties encountered in the teaching process and they need to be explored on their own. Based on the above reasons, it is difficult to avoid problems in the teaching process of the costume art design professional. Next, some of the more common problems are analyzed.

\subsection{The unclear positioning of costume art design major and the biased overall orientation of the teaching}

The costume art design profession belongs to an emerging profession, there is not much experience to refer to, in the teaching process many paths are explored by oneself. The slightest negligence in the choice of teaching direction may have an impact on the general direction. In the positioning of the costume art and design profession, the professional orientation may be unclear because of the leader's own problems: Due to the relatively short history of the garment art design profession, the leader's working experience is not sufficient, and most of the learning is theoretical. Knowledge may be biased in the choice of teaching direction; in the process of making decisions, due to some limiting factors, no reasonable decision can be made. When there is a deviation in the overall direction of teaching, it will cause problems in the entire teaching work.

\subsection{Improper position of teachers and students in the costume art design major due to other factors.}

With the continuous development of society, various cultures in the society have begun to appear slowly, filled with people's attention, and people of all kinds will appear. With the development of science and technology, the means for people to understand the world are increasing. Nowadays, people can learn about the events happening in the entire world through social networks such as WeChat and Weibo. The speed of cultural communication is also accelerating. Everyone has their own choice cognitive system, and each person will have different treatment for the received information. Multiculturalism will also have a great influence on the teachers and students of the costume arts design profession, and it will lead teachers and students to fail to make a reasonable position on their profession. For example, in the current Red Net culture, some Net Red will promote their own clothing through certain social software, so as to increase the sales of their clothes and increase their own income. These red-clothing cultures are accompanied by many people on the Internet. There is an impact, which may include students and teachers of costume art design. When there is a conflict between cultures that are popular in certain popular culture and costume art and design professions in the society, it may lead to some students and teachers ambiguous about their professions, and have an impact on teaching work and daily learning.

\subsection{The lack of resources provided by various parties in the practical teaching of costume art design major}

In recent years, various aspects of society have paid more and more attention to the apparel art design profession, and the country's attention to the profession has also been increasing. The state has increased the development funds for the costume art design profession, and the development of the garment design industry. With certain equipment support, it should be developed rapidly. However, in the teaching process, it is impossible to make full use of practical equipment. Students have not fully grasped the value of these equipments and they have not fully grasped practical skills. The cause of this problem may be caused by the teacher, or it may be caused by the student. In terms of teachers, some schools in the establishment of the costume art and design professional, 
teacher strength is weak, the teacher's own level can not be guaranteed, in teaching, lack of teaching experience, can not reasonably guide students. In the teaching process, the teachers themselves are not familiar with the practice facilities and guide students to practice without even talking about. In terms of students, students do not cooperate with teachers' teaching work, and their enthusiasm for learning is relatively low. In the process of practical teaching in the costume arts design professional, the teacher is required to guide students in practical learning and operation, so that the students master the relevant skills. If the equipment is not fully used in practice, the students' knowledge is not learned. The application will result in the ineffectiveness of practical teaching.

\subsection{The small number of practical courses offered by costume art design major and fewer opportunities for students to practice.}

Since the beginning of the 21st century, education has undergone continuous reforms. The core of the reform is to increase students' practical ability and improve their core qualities in the process of education. In the teaching process of costume art design, students are required to practice and improve their hands-on skills. In school education, the cost of offering practical courses is higher than that of theoretical courses. In some schools, there may be the phenomenon of reducing practical courses to reduce the cost of the school. This leads to fewer opportunities for students to practice and practice. Sex teaching has little effect.

\section{Specific Methods for Practical Teaching of Costume Art Design}

Apparel art design students require higher practical ability. Therefore, the school must actively develop practical teaching courses. In the process of teaching, it must choose the right learning method, carry out effective practical teaching, and effectively improve students. The professional skills of costume art design, followed by analysis of the practical methods of practical teaching of costume art design.

\subsection{Proper positioning of costume design major to ensure the correctness of the overall teaching orientation}

To conduct a professional specific orientation is the premise of the entire professional teaching activities. When conducting professional orientation, we must not take it lightly, collect all the data for the most scientific and most reasonable position, and lay a good foundation for the future teaching work. In the course of positioning, the situation of "dictatorship" of one person is reduced, and a decision-making body is formed. Everyone will think of ways and brainstorm. In the process of selecting members of the decision-making body, we must consider the following aspects: whether the members have a certain degree of literacy; whether there is a certain amount of teaching experience; whether there is a certain degree of social research. Select the most suitable person to form a decision-making body and make the most accurate decision-making position. In the process of making decisions, it is not only necessary to take into account the cultural orientation of the discipline, but also to consider social factors and fully understand the market conditions. In the decision-making, we must also listen to the students' opinions, understand the students' ideas, combine the correct scientific methods with the students' ideas, find the most suitable practical teaching methods, and help students develop their own practical abilities.

\subsection{Carry forward correct values in daily learning and train students' correct thinking}

Every aspect of society's culture has a great impact on the students' own values. It may cause some of the students' values to be incorrect and do not have a correct understanding of the costume art design profession. The learning efficiency is low. In the daily learning process, we must do a good job of the students' ideological work, so that students have a correct understanding of the costume art design profession. Schools can organize students to participate in a number of professional lectures, so that students fully understand the nature of the costume art design professional, have a clear position for themselves. In the ordinary education of students, students are taught to distinguish the quality of the culture, to improve the ability of the students to 
distinguish themselves, so that the students themselves understand what the culture is good and what the culture is not good. It cannot be considered that this culture is Yes, help students develop correct values and outlook on life. In the process of teaching, teachers can also give students relevant ideological guidance to improve their enthusiasm for learning and improve their school's rate.

\subsection{Full use of various resources in the teaching process for effective practical teaching}

In recent years, the state has increased investment in this area and improved various teaching equipment. In the course of practical teaching, the role of these teaching equipments should be fully utilized. In the process of practical teaching, students are guaranteed to have a dominant position so that each student can have hands-on opportunities. In the process of practical teaching, the teacher first introduces the students to the main contents of practical teaching. After that, the students are taught how to use the relevant equipment. During the specific practice of the students, the teacher can walk around and find out that the students' problems are promptly performed. Correct and improve students' practical ability.

\subsection{Strengthen the cooperation between schools and enterprises, provide more practical opportunities for students, and improve students' practical ability}

Cooperation between schools and enterprises is a common practice adopted by many colleges and universities. The majority of school professors give students theoretical knowledge, and most of the practical experience still needs to be derived from future work. Cooperation between schools and enterprises allows students to familiarize themselves with their professional counterparts in advance and avoid embarrassing situations that are unclear after entering the community in the future. Organizing students to practice in business is also a kind of practical teaching, allowing students to familiarize themselves with various work processes and accumulate more work experience in the process of business implementation. The cooperation between enterprises and schools can also get certain benefits. The quality of the work experience of the staff who have experienced professional education in the school is higher than most of the staff. Students can improve the quality of work during the internship. During the internship process of the company, there will be relevant cooperation with the workers in the company. During the process of cooperation, the skilled work staff will feel their own work literacy and encourage the students to develop in a good direction. During the implementation of the company, students can personally feel the ever-changing costume art design market, the real difficulty in experiencing professional work, and can also feel the changes that their own majors can bring to society and improve their professional confidence. During the student's internship at the factory, the teacher must ensure the personal safety of the student and solve related problems for the student in time.

\section{Conclusion}

Social and cultural diversity, different cultural styles will have different clothing and clothing, and the professional design of costume arts will play an increasingly important role in the production of society. In the teaching of costume art and design, we must focus on improving students' professional qualities and practical abilities, give full play to the role of this professional culture and education, and train a group of talents in costume design to invest in social production. Design high-quality clothing and invest in society to improve people's satisfaction. In the process of teaching, reference can be made to the successful cases of fashion design teaching, learn from others' excellent experience, improve their own teaching methods, increase communication with students, improve teaching quality, and cultivate qualified professionals for the society.

\section{References}

[1] Zhang Xiaodan. Some Considerations on Practical Teaching of Costume Art Design[J]. The House of Drama, 2016(24):245-245. 
[2] Xuan Wei. Several Thoughts on Strengthening the Practical Teaching of Environmental Art Design Specialty[J]. Entrepreneurship and Design, 2011(5):89-91.

[3] Hu Lei, Zhu Xiuli. Some Considerations on the Practical Teaching of Costume Art Design[J]. Journal of Zhejiang Institute of Technology, 2007(3):330-332.

[4] Qian Sun. Some Reflections on Sketch Teaching of Art Design Specialty [J]. Journal of Chifeng College (Philosophy and Social Science Edition),2010(10):191-193. 